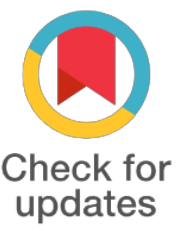

${ }^{*}$ For correspondence:

nvthuan@hcmiu.edu.vn

Competing interests: The authors declare that no competing interests exist.

Received: 2017-08-17

Accepted: 2017-08-25

Published: 2017-09-05

Copyright The Author(s) 2017. This article is published with open access by BioMedPress (BMP).

This article is distributed under the terms of the Creative Commons Attribution License (CC-BY 4.0) which permits any use, distribution, and reproduction in any medium, provided the original author(s) and the source are credited.

\section{Effects of oocytes collection and electro- activation protocols on maturation and preimplantation development of parthenogenetic diploid porcine embryos}

\author{
Le Thi Thu Thuy, Nguyen Ba Tu, Bui Hong Thuy, Nguyen Van Thuan* \\ Cellular Reprogramming Laboratory, department of Biotechnology School of Biotechnology, \\ HCM International University- Vietnam National University
}

\section{Abstract}

Advances in porcine embryos production have been impaired by the in vitro maturation (IVM) system and in vitro developments (IVD) are still not optimized. The present study was undertaken to determine the effects of different oocytes collection methods (aspiration and dissection) on oocytes maturation and combine with the different electro-activation protocols on in vitro pre-implantation development of parthenogenetic diploid porcine embryos. The results showed that dissection method was significantly higher both in quantity $(87.23 \%, p$ $<0.05)$ of matured oocytes and in the rate of oocytes with very good quality (53.00\%) compared with aspiration method $(62.00 \%, 30.22 \%$; respectively). We further accessed the quality of matured oocytes competence via parthenogenetic embryo development. Using four electroactivation protocols, we found that the electro-activation condition had no effect on the development of embryos to the 2-cell, 4-cell and 8-cell stages. However, the oocytes activated by the $60 \mathrm{~V} / \mathrm{cm}$ amplitude of pulse group had less (41.33\%; $\mathrm{p}<0.05$ ) development at the morula stage than $90 \mathrm{~V} / \mathrm{cm}, 100 \mathrm{~V} / \mathrm{cm}$ and $150 \mathrm{~V} / \mathrm{cm}$ amplitude of pulse groups $(73.99 \%, 67.62 \%, 72.55 \%$; respectively). The embryos develop to blastocyst stage was highest in the group induced by $90 \mathrm{~V} / \mathrm{cm}$ electro pulse was $71.76 \%$ compared to $100 \mathrm{~V} / \mathrm{cm}, 150 \mathrm{~V} / \mathrm{cm}$, and $60 \mathrm{~V} / \mathrm{cm}(62.86 \%$, $62.05 \%$, and $37.63 \%, \mathrm{p}<0.001$, respectively). We conclude that the combining of dissection method for porcine oocytes collection and electro-activation with the amplitude of pulses $90 \mathrm{~V} / \mathrm{cm}$ can enhance both the activation success and development competition in in vitro preimplantation parthenogenetic diploid porcine embryos.

\section{Keywords}

parthenogenesis, aspiration, dissection, electro-activation, pre-implantation development

Funding

References 